considerable. The length of the left antler is 3 feet 9 inches; of the right antler, 4 feet. The first branch was 2 feet long, the next was 20 inches; there was another 17 inches long, and the last was 9 inches, the rest being broken off. The distance from tip to tip was almost 9 feet, but the palm was broken off. The Museum of the town of Banbridge, Co. Down, has lately been enriched by a perfect specimen of this species, obtained in the immediate neighbourhood.

At the meeting on Feb. 2, a paper was read by the President, G. C. Hyndman, Esq., On Field-Naturalists' Clubs, and how they should be carried on.-R. T.

\title{
CORFESPONDENTEE.
}

\section{FORMER EXTENSION OF THE COAL-MEASURES.} To the Editor of the Geological Magazine.

Sir,-There are some 'auld-warld' notions in Geology, resting on the authority of great names, or on that of a former general acceptation, which every now and then reappear, to the no small astonishment of those who had deemed them long ago tacitly abandoned. Two of these notions crop out in the genial and excellent review of Professor Ramsay's Lectures in your last number. These are, 1 st. That our present coal-basins were originally formed as basins, like that of the Miocene basin of Bovey Tracey. 2ndly. That ripplemark (more properly 'ripple' or 'current-mark') proves the neighbourhood of a 'sea-margin.'

A ripple on the surface of a bed proves the existence of a current in the water that flowed over it, just as a ripple on the surface of the water proves the existence of a current in the air that flows over it. It is only an evidence of the shallowness of that water to this extent, that currents of the requisite strength are more frequent in shallow water than in deep. Possibly, in very deep water, even if there were a current at the bottom, the pressure of the water might prevent the heaping up of the little ridges ; but this is a point of physics on which I offer no opinion.

As to the Coal-measures, I would declare, as a practical geologist, my belief that wherever in the British Islands there is Carboniferous Limestone, it was formerly covered by Coal-measures in some form or other; and, moreover, that wherever there is true Old Red Sandstone, it was formerly covered by the rest of the Carboniferous formation in some form or other.

The South-Welsh Coal-field must formerly have been continuous with that of the Forest of Dean, and with that of the Clee Hills and Shropshire; the Malvern and other hills rising, perhaps, through it like islands. The Coal-measures of Nottinghamshire and Yorkshire must once have spread over what is now the great northern anticlinal to those of Cheshire and Lancashire; and there can be no doubt that these now spread, in a more or less ruined condition, beneath 
the New Red Sandstone plain of Cheshire to those of North Wales. But more than that, I take it that the patch of Carboniferous Lime.stone near Corwen, together with the Flintshire escarpments, makes it almost certain that the whole Carboniferous formation spread formerly over the greater part of North Wales, with just a few island-peaks of older rocks, perhaps, rising up through it. In short, I believe that, with the possible exception of a few isolated points there and elsewhere, as in Cumberland and about the Southern Highlands of Scotland, the whole of the Southern half of Scotland and all England and Wales were, at the close of the Carboniferous period, covered by level and continuous sheets of Coal-measures.

Local thinnings and thickening of the beds there were, doubtless, in all directions.

As to Ireland, I have long taught in my lectures, and I believe demonstrated, that, with the exception of a few small isolated peaks of the Older Palæozoic rocks, it also was at the same period one great plain of Coal-measures, whether above or under water.

How far the Carboniferous Limestone of the Isle of Man proves that the English and Irish Carboniferous formations were then connected across what is now the Irish Sea, I forbear to decide. My own private opinion is that they were more or less connected, just as at a later period the Red Marls and Lias of Antrim were continuous with those of Cheshire, Worcestershire, and Gloucester.

$I$ almost fear that I am writing what to many persons will appear mere common-place truisms; but the expressions of your Reviewer have induced me to run the risk of that imputation rather than that any persons should retain what $I$ believe to be erroneous and narrow views in our science.

The portions of the Palæozoic rocks still left in our islands are only the mere ruined fragments and foundations of those that once existed. The hole in the Chalk that occurs in the Wealden district excites attention because, from its comparatively slight extent, people can see that it is a hole, while the far more extensive destruction of the older rocks has been so great that the former continuity of their fragments is ignored or discredited.-Yours, \&c.,

Debuin : Feb. 6, $186 \overline{5}$.

J. Beete Jukes.

\section{CARBONIFEROUS SANDSTONE WITH SURFACE-MARKS.}

[Plate IV.]

To the Editor of the Geological Magazine.

Sir,- Having lately obtained a slab of one of the Carboniferous sandstones (a few feet below the 'Yard-seam' and above the 'Fivequarter-seam' at Bowden-close, in the Bishop-Auckland Coal-field, Co. Durham), which bears about fifty impressed hoof-shaped marks, and not being aware that any such markings, usually supposed to be foot-prints of some animal, have been found lower down than the 